\title{
Penyidikan Tindak Pidana Perdagangan Orang melalui media sosial
}

\section{Investigation of human trafficking through social media}

\author{
Dian Sukma Purwanegara ${ }^{\bowtie}$ \\ Polres Mojokerto \\ Mojokerto, 61321, Jawa Timur, Indonesia \\ E-mail of corresponding author: dian.sukma.purwanegara@pasca.unair.ac.id
}

\begin{abstract}
Abstrak
Human trafficking merupakan bentuk kejahatan yang paling tidak disadari oleh korban. Modusnya seringkali bersembunyi di balik kondisi kesulitan ekonomi dan finansial dengan menawarkan pekerjaan yang dibutuhkan dan membuat korban tidak berkesempatan bersikap kritis terhadap pekerjaan yang ditawarkan karena terdesak untuk hanya berpikir tentang bagaimana melanjutkan hidup. Tujuan penelitian ini adalah untuk mengetahui penyidikan tindak pidana perdagangan orang melalui media social. Dalam penelitian ini pendekatan yang digunakan adalah kualitatif dengan menggunakan metode studi kasus (case study). Pelaku perdagangan orang melalui media sosial dengan modus prostitusi melakukan pendekatan pada korbannya melalui cara pemenuhan kebutuhan emosional sehingga terjalin hubungan yang baik antara pelaku dan korbannya. Selanjutnya jika ada ketetarikan maka pelaku menggunakan Grup Line yang berisi akun-akun pria yang bersedia membooking. Modus yang paling inti selanjutnya adalah modus TPPO (Tindak Pidana Perdagangan Orang) melalui tenaga kerja ilegal. Disinilah perdagangan orang di mulai. Kendala penanganan tindak pidana perdagangan orang dari faktor hukumnya adalah tidak adanya aturan yang secara khusus mengatur mengenai perdagangan orang dengan media sosial sebagai sarananya serta adanya ambiguitas istilah korban dalam UU PTPPO (Undang-undang Pemberantasan Tindak Pidana Perdagangan Orang).
\end{abstract}

Kata kunci: kejahatan; modus; prostitusi; ilegal; pidana

\begin{abstract}
Human trafficking is a crime of which most of its victims are not aware of. It hides behind poor economic conditions and financial hardship, offering jobs that are desperately needed by those in such situation. It leaves its victims with no opportunity to be critical of the jobs offered because they are forced to only focus on how to make a living. The purpose of this research is to examine the investigation of human trafficking through social media. The research was done as a qualitative case study. The perpetrators of human trafficking for prostitution use social media to approach their victims by providing fulfillment for the victims' emotional needs. Doing such, the perpetrators then build a good relationship with their victims. After that, if the victims are interested, the perpetrators use Line Group which contains accounts of potential clients. Another practice of human trafficking is for illegal labor. This is where the actual human trafficking begins. The study also identifies some legal factors that hinder the handling of human trafficking cases, namely: the unavailability of a specific law that controls human trafficking using social media and the ambiguity of how the term victim is defined in the Law on Elimination of Human Trafficking Crimes.
\end{abstract}

Keywords: crime; modus operandi; prostitution; illegal; criminal

\section{Pendahuluan}

Human trafficking merupakan masalah nasional dan internasional yang sudah terjadi sejak lama (Makarao 2014; Winterdyk \& Reichel 2010; Sanchez \& Stark 2014; Carr 2012; Whitman \& Gray 2015; Azad 2018; Belanger 2014; McClain \& Garrity 2011). Sayangnya, tindak kejahatan ini jarang disadari oleh korban. Modusnya seringkali bersembunyi di balik kondisi kesulitan ekonomi dan finansial dengan menawarkan pekerjaan yang dibutuhkan dan membuat korban tidak berkesempatan bersikap kritis terhadap pekerjaan yang ditawarkan karena terdesak untuk hanya berpikir tentang bagaimana melanjutkan hidup (Wheaton et al. 2010; Prabuningrat 2015; Anggrahini 2016). Keadaan Indonesia yang belum baik secara ekonomi membuat masyarakat memiliki orientasi yang tinggi pada kehidupan finansial. Situasi ini mendorong masyarakat terutama kalangan bawah untuk melakukan berbagai cara agar dapat memenuhi kebutuhan-kebutuhan hidupnya. Mereka amat beresiko terperosok 
dalam kondisi sosial berupa perdagangan orang. Dorongan untuk hidup layak dengan cara apapun melemahkan mereka secara psikis. Apalagi jika dialami oleh para remaja dan anak-anak, bayangan tentang kehidupan yang mapan membuat mereka kurang mampu menyadari bahaya di balik kasus human trafficking tersebut.

Mayoritas korban perdagangan orang atau human trafficking adalah perempuan dan anak (Wulandari \& Wicaksono 2014; Hanifah 2008; Suyanto 2013; Honeyman et al. 2016; Plantika 2019). Korban yang dimaksud dalam kasus human trafficking adalah seseorang yang mengalami penderitaan psikis, mental, fisik, seksual, ekonomi, dan/atau sosial akibat tindak pidana perdagangan orang. Sementara yang dimaksud dengan anak adalah seseorang yang belum berusia 18 (delapan belas) tahun, termasuk anak yang masih dalam kandungan. Meskipun demikian, pria dewasa juga berpotensi menjadi korban, namun kenyataannya perempuan dan anak memiliki potensi dan resiko yang lebih tinggi untuk menjadi korban human trafficking.

Penggunaan jejaring sosial seperti Facebook, instagram atau media sosial lainnya dimotivasi oleh dua kebutuhan primer yaitu kebutuhan untuk bersama dan kebutuhan untuk presentasi diri (Engkus \& Saminnurahmat 2017). Remaja memiliki kebutuhan untuk memiliki dan bersama daarn jaringan sosialnya serta meningkatkan hubungan interpersonal untuk mengaktualisasikan diri melalui keterampilan interpersonal. Pengungkapan diri merupakan ketrampilan interpersonal yang penting dalam perkembangan remaja. Namun sebagian besar dari remaja memiliki ketrampilan sosial yang rendah. Sedangkan hal-hal yang berkontribusi secara positif terhadap kebutuhan presentasi diri adalah neurotisisme, narsisme, rasa malu, dan harga diri.

Dengan berbagai aktivitas di media sosial itulah menyebabkan kerentanan bagi remaja untuk terjerumus dalam lingkaran perdagangan orang (Whiters 2019; Sarkar 2015; Latonero 2011; Fraser 2016). Sebagaimana kejadian perdagangan orang dengan menggunakan media sosial yang juga kerap terjadi di wilayah hukum Polda Jawa Timur. Misalnya mengenai kasus pada tahun 2007 mengenai dua warga Surabaya ditangkap karena menjajakan anak di bawah umur lewat media sosial Facebook. Korban yang ditawarkan rata-rata masih berusia 14-17 tahun, dengan tarif rata-rata Rp 1 juta. Penangkapan ini menambah panjang daftar kasus perdagangan anak yang terungkap di Kota Surabaya, Jawa Timur. Pola rekrutmen korban berdasarkan penjelasan tersangka adalah melalui media sosial. Ia memanfaatkan kerentanan anak dan remaja yang tanpa dibekali pemahamam penggunaan media sosial yang cukup. Pengungkapan, penanganan serta upaya pemberantasan perdagangan orang yang dilakkan melalui media sosial perlu mendapat porsi khusus melalui suatu penelitian ilmiah untuk mengungkapkan berbagai sebab kendala dalam penegakan hukumnya. Oleh karena itu berdasarkan uraian latar belakang yang telah dikemukakan diatas penulis tertarik untuk mengangkat tema tentang "Penyidikan Tindak Pidana Perdagangan Orang Melalui Media Sosial".

Tindak pidana perdagangan orang, istilah perdagangan orang menurut Undang-Undang Republik Indonesia Nomor 21 Tahun 2007 tentang Pemberantasan Tindak Pidana Perdagangan Orang Pasal 1 ayat (1), (7), dan (8) yang dimaksud dengan: (1) Perdagangan orang adalah tindakan perekrutan, pengangkutan, penampungan, pengiriman, pemindahan, atau penerimaan seseorang dengan ancaman kekerasan, penggunaan kekerasan, penculikan, penyekapan, pemalsuan, penipuan, penyalahgunaan kekuasaan atau posisi rentan, penjeratan utang atau memberi bayaran atau manfaat, sehingga memperoleh persetujuan dari orang yang memegang kendali atas orang lain tersebut, baik yang dilakukan di dalam negara maupun antar negara, untuk tujuan eksploitasi atau mengakibatkan orang tereksploitasi, (7) Eksploitasi adalah tindakan dengan atau tanpa persetujuan korban yang meliputi tetapi tidak terbatas pada pelacuran, kerja atau pelayanan paksa, perbudakan atau praktik serupa dengan perbudakan atau praktik serupa dengan perbudakan, penindasan, pemerasan, pemanfaatan fisik, seksual, organ reproduksi, atau secara melawan hukum memindahkan atau mentransplantasi organ dan/atau jaringan tubuh atau memanfaatkan tenaga atau kemampuan seseorang oleh pihak lain untuk mendapatkan keuntungan baik materiil maupun immateriil, (8) Eksploitasi seksual adalah segala bentuk pemanfaatan organ tubuh seksual atau organ tubuh lain dari korban untuk mendapatkan keuntungan, termasuk tetapi tidak terbatas pada semua kegiatan pelacuran dan pencabulan. 
Media sosial sendiri didefinisikan sebuah media online, dengan para penggunanya bisa dengan mudah berpartisipasi, berbagi, dan menciptakan isi meliputi blog, jejaring sosial, wiki, forum dan dunia virtual. Blog, jejaring sosial dan wiki merupakan bentuk media sosial yang paling umum digunakan oleh masyarakat di seluruh dunia. Kaplan \& Haenlein (2010) mendefinisikan media sosial sebagai sebuah kelompok aplikasi berbasis internet yang membangun di atas dasar ideologi dan teknologi Web 2.0, dan yang memungkinkan penciptaan dan pertukaran user-generated content.

Media sosial adalah media online yang mendukung interaksi sosial. Sosial media menggunakan teknologi berbasis web yang mengubah komunikasi menjadi dialog interaktif (Ardianto 2004). Beberapa situs media sosial yang populer sekarang ini antara lain: Blog, Twitter, Facebook, Instagram, Path, dan Wikipedia. Definisi lain dari sosial media juga di jelaskan oleh Van Dijk media sosial adalah platform media yang memfokuskan pada eksistensi pengguna yang memfasilitasi mereka dalam beraktivitas maupun berkolaborasi. Karena itu, media sosial dapat dilihat sebagai fasilitator online yang menguatkan hubungan antar pengguna sekaligus sebagai sebuah ikatan sosial (Nasrullah 2017).

Menurut Soerjono Soekanto, penegakan hukum bukanlah semata-mata berarti pelaksanaan perundangundangan, walaupun di dalam kenyataan di Indonesia kecenderungannya adalah demikian, sehingga pengertian law enforcement begitu populer. Selain itu, ada kecenderungan yang kuat mengartikan penegakan hukum sebagai pelaksanaan keputusan-keputusan hakim. Perlu dicatat, bahwa pendapatpendapat yang agak sempit tersebut mempunyai kelemahan-kelemahan, apabila pelaksanaan perundang-undangan atau keputusan-keputusan hakim tersebut malahan mengganggu kedamaian di dalam pergaulan hidup.

Faktor-Faktor yang mempengaruhi penegakan hukum, disebutkan bahwa faktor-faktor yang mempengaruhi penegakan hukum adalah: (1) Faktor hukumnya sendiri, yang di dalam hal ini akan dibatasi pada undang-undang saja, (2) Faktor penegak hukum, yakni pihak-pihak yang membentuk maupun menerapkan hukum, (3) Faktor sarana atau fasilitas yang mendukung penegakan hukum, (4) Faktor masyarakat, yakni lingkungan di mana hukum tersebut berlaku atau diterapkan, (5) Faktor kebudayaan, yakni sebagai hasil karya, cipta, dan rasa yang didasarkan pada karsa manusia di dalam pergaulan hidup (Soekanto 2011).

\section{Metode Penelitian}

Tipe penelitian ini adalah penelitian sosiologi hukum. Penelitian yang menggunakan pendekatan hukum dalam melihat fakta empiris. Dalam penelitian ini pendekatan yang digunakan adalah kualitatif dengan menggunakan metode studi kasus (case study) (Sanapiah 1990; Bungin 2004). Sementara itu pendekatan masalah yang digunakan meliputi pendekatan perundang-undangan, pendekatan konsep dan studi kasus. Pendekatan perundang-undangan yaitu dengan meneliti perundang-undangan yang terkait dengan isu hukum yang diteliti yaitu tindak pidana perdagangan orang (Yin 2011).

Sumber data atau informasi meliputi data primer dan data sekunder. Data primer adalah data yang diperoleh secara mentah kemudian di analisis lebih lanjut, berasal dari masyarakat secara langsung atau aparat penegak hukum yang berhubungan dengan penelitian ini. Sedangkan data sekunder adalah data yang diperoleh melalui studi kepustakaan dengan mempelajari literatur, tulisan ilmiah, peraturan perundang-undangan, serta dokumen yang diperoleh instansi yang terkait dengan obyek penelitian dan permasalahan yang diangkat. Selain itu, salah satu tahap yang paling penting dalam penelitian adalah menganalisis data yang telah diperoleh. Analisis data dalam penelitian ini menggunakan analisis kualitatif. Dalam penelitian kualitatif dapat dikonstruksi sebagai satu strategi penelitian yang biasanya menekankan kata-kata daripada kuantifikasi dalam pengumpulan dan analisis data, menekankan pendekatan induktif untuk hubungan antara teori dan penelitian, yang tekanannya pada penempatan penciptaan teori (generation of theory). 


\section{Hasil dan Pembahasan}

\section{Modus operandi perdagangan orang melalui media sosial}

Pertama, perdaganan orang dengan modus prostitusi atau ekspolitasi seksual. Pelaku perdaganan orang selain mengetahui sisi sisi emosional korbannya juga mengetahui benar bagaimana memanfaatkan media sosial untuk memuluskan aksinya. Teknologi memainkan peran yang lebih besar dalam perdagangan manusia, hal ini memungkinkan beberapa pelaku perdagangan untuk dapat mengeksploitasi anak muda tanpa bertemu langsung. Tetapi setelah relasi dan kepercayaan terbangun maka para pelaku perdagangan orang ini akan mengajak bertemu calon korbannya. Mengenai modus penawaran Pelaku perdagangan orang pada calon "pengguna jasanya" penulis melakukan observasi lanjutan dari berbagai kasus yang ditangani di Subdit IV Renakta Ditreskrimum Polda Jatim sehingga didapatkan modus utama yang digunakan oleh pelaku tindak pidana perdagangan orang untuk menawarkan jasanya terkait maraknya peggunaan media sosial saat ini yakni dengan memanfaatkan fitur pada aplikasi media sosial yakni fitur "Grup" sebagai rekrutmen korban serta penawaran transaksi seksual.

Kedua, perdagangan orang dengan modus tenaga kerja ilegal. Untuk modus-modus pemanfaatan tenaga atau kemampuan secara ilegal yang biasa dilakukan pelaku agar iklannya menarik berdasarkan informasi dari informan antara lain melalui rekrutmen tenaga kerja palsu di medsos yang bisa jadi modus perdagangan orang terselubung. Untuk menghindarinya masyarakat harus mengetahui cirinya, diantaranya gaji yang ditawarkan selangit tapi tidak membutuhkan pengalaman kerja, menggunakan alamat email gratisan sebagai informasi pekerjaan misalnya pakai yahoo atau gmail. Masyarakat juga harus bisa cross cek keberadaan perusahaan penampung tenaga kerja, apakah legal atau abal-abal. Terkadang mereka mencatut perusahaan legal tapi pakai kontak info dengan nomer HP. Kan ndak masuk akal. Harus benar-benar dianalisis dengan matang dan banyak bertanya pada yang lebih ahli. Masyarakat yang tahu itu palsu jangan asal share.

Ketiga, perdagangan orang dengan modus adopsi secara ilegal. Proses pengangkatan anak yang tidak mengikuti prosedur yang semestinya tentunya akan menyebabkan minimnya pengawasan terhadap kasus penelantaran anak. Menurut catatan Kementerian Sosial, sepanjang tahun 2009 ada 50 orang anak diadopsi oleh warga negara Indonesia. Selanjutnya di tahun 2010 tercatat 48 anak, dan di tahun 2011 tercatat 29 anak diadopsi. Sementara untuk adopsi lintas negara pada tahun 2009 dan 2010 masing-masing 11 orang anak, pada tahun 2012 sebanyak 8 orang anak dengan 9 orang lagi masih menunggu proses. Namun demikian, jumlah jelas bukan angka sebenarnya, karena realitasnya pasti lebih besar. Dari penelusuran tim Cyber Troops Polda Jatim terhadap akun Instagram bernama "Konsultasi Hati" ini, polisi menemukan bukti penjualan anak yang dilakukan empat orang tersebut. Bayi yang dijual tersebut dipatok dengan harga Rp 22 juta. Dari harga tersebut, bidan mendapat Rp 5 juta serta sisanya untuk pelaku AP. Saat melakukan aksinya, pelaku menyasar kepada calon ibu yang tidak menghendaki bayi maupun tidak memiliki biaya persalinan dan perawatan. Setelah berhasil merebut perhatian korbannya, pelaku meneruskan aksinya melalui percakapan di WhatsApp.

Dalam aksinya ini, pelaku berhasil menarik perhatian 600 pengguna yang mengikuti akun Instagramnya. Pemilik akun Instagram tersebut membuat tulisan beberapa point untuk menarik minat korbannya, seperti merawat anak lahir di luar nikah, kehamilan yang tidak dikendaki ibu maupun kelahirannya dan anak terlantar. Modus itu digunakan pelaku dengan berdalih agar bayi-bayi tersebut tidak digugurkan dan terlantar.

Pelaku juga browsing mengenai siapa yang mau mengadopsi anak untuk kemudian dilakukan penawaran olehnya. Dari beberapa pengikut instagramnya, ia kemudian berhasil menarik perhatian pengguna Instagram bernama LR. Karena tertarik, LR menawarkan bayinya yang berumur 11 bulan lantaran tidak bisa merawat. Kemudian pelaku mengajak LR untuk bertemu di Bungurasih, Surabaya, untuk menyerahkan bayinya. Setelah mendapatkan bayi, pelaku membawanya ke Bali untuk diserahkan ke pembelinya bernama NS, dan seorang bidan KS. Dari hasil penyelidikan dan identifikasi polisi, AP menjadi dalang dari pemilik akun tersebut. Dari keterangannya, pelaku mengaku 
mengetahui aksinya itu melanggar hukum, sebab layanan konsultasi dan sistem adopsi bayi itu tidak berbadan hukum. Niatnya membuat layanan konsultasi itu didapatkannya setelah lulus dari jurusan Kesejahteraan Keluarga di sebuah kampus di Surabaya.

\section{Praktik penyelidikan dan penyidikan atas tindak pidana perdagangan orang dengan sarana media sosial}

Untuk mengimbangi laju perkembangan tingkat kejahatan yang dilakukan melalui media sosial maka perlu adanya Tim khusus dari penegak hukum yang secara intensif memantau berbagai isyu, tranding topic, serta berbagai potensi kriminal yang terjadi di dunia maya. Termasuk dengan maraknya praktik tindak pidana perdagangan orang melakui media sosial, maka pada tahun 2017 Bidhumas Polda Jatim membentuk Cyber Troops. Salah satu tugas cyber troops adalah melakukan cyber patrol yakni patroli atau jelajah dunia maya untuk mengetahui atau mencegah informasi hoax, pendeskriditan Institusi, hate speech atau ujaran kebencian, radikalisme serta tindak pidana lain seperti perdagangan atau prostitusi online.

Langkah pertama dalam mengorganisasikan cyber troops adalah dengan membuat dan mengintegrasikan akun media online maupun media sosial yang dimiliki masing-masing wilayah. Saling terintegrasi antara Polda dengan Polres dengan Polsek, dengan cara saling berteman, follow antar media sosial yang dimiliki (Facebook/fanpage facebook, lnstagram, Twitter, dll). Selanjutnya membuat group WA/Telegram/Line dan menunjuk 1 anggota yang berkompeten mengetahui IT. Penulis memberikan mengenai gambaran mengenai penyidikan kasus yang menjerat pelaku yakni PFA (21 tahun), KSN (47 Tahun) dan dengan korban atas nama EL (16 tahun) serta AS (20 tahun) terkait praktik perdagangan orang dengan menggunakan sarana media sosial.

Dalam praktik penanganan kasus tersebut, Tim Cyber Troops Polda Jatim saat melakukan kegiatan cyber patrol, mengindikasikan adanya transaksi yang mengarah pada kegiatan perdagangan orang melalui Group Watsapp (WA)/LINE. Tim Cyber Troops kemudian melakukan penyelidikan secara tertutup terhadap dugaan perdagangan orang ini. Selanjutnya kegiatan penyelidikan lanjutan dalam kasus perdagangan orang sebagaimana temuan awal oleh Tim Cyber Troops tersebut dilakukan penyidik Subdit IV Renakta Ditreskrimum Polda Jatim dengan mendatangi TKP yakni di Hotel Malibu yang diduga terjadi tindak pidana. Hal ini sebagaimana berdasarkan Pasal 24 Perkap 14 Tahun 2012 yang menyatakan bahwa penyelidikan dilaksanakan melalui kegiatan pengolahan TKP untuk mencari dan mengumpulkan keterangan, petunjuk, barang bukti, identitas tersangka, dan Saksi/korban untuk kepentingan penyelidikan selanjutnya; mencari hubungan antara saksi/korban, tersangka, dan barang bukti; dan memperoleh gambaran modus operandi tindak pidana yang terjadi.

Penyelidikan lanjutan dengan mendatangi TKP dilakukan pada tanggal 4 September 2017 Kanit 1 Renakta beserta team menuju Hotel Malibu Jl. Raya Ngagel No. 127 Surabaya yang diduga sebagai tempat yang diduga terjadi tindak pidana Perdagangan Orang dan atau Pelacuran anak. Penyelidikan ini disertai dengan Surat Perintah Tugas Nomor : SP. Gas/2016/IX/2017/Ditreskrimum, tanggal 4 September 2017.

Selanjutnya di Ditreskrimum Polda Jatim dilakukan pemeriksaan kasus dengan dibuatnya laporan Polisi oleh Unit I Renakta Subdit IV. Berdasarkan Pasal 5 ayat (1) Laporan Polisi/ Pengaduan terdiri dari Laporan Polisi Model A dan Laporan Polisi Model B. Mengenai Laporan Polisi Model A adalah Laporan Polisi yang dibuat oleh anggota Polri yang mengalami, mengetahui atau menemukan langsung peristiwa yang terjadi. Sedangkan Laporan Polisi Model B adalah Laporan Polisi yang dibuat oleh anggota Polri atas laporan/ pengaduan yang diterima dari masyarakat. Untuk kasus ini digunakan Laporan Polisi Model A, yang mana tindak pidananya diketahui berdasarkan cyber patrol dari Tim Cyber Troops Bidhumas yang kemudian dilakukan penanganan lanjutan oleh Subdit IV Renakta Ditreskrimum Polda Jatim dengan membuat laporan Polisi Nomor: LP.A/58/ IX/2017/UM/JATIM tanggal 4 September 2017. 
Proses berikutnya Direktur Reserse Kriminal Umum Polda Jatim menerbitkan surat perintah penyidikan Nomor: SP. Sidik/1387/IX/2017/Ditreskrimum, tanggal 4 September 2017 untuk kepentingan penyidikan peristiwa pidana yang dilakukan oleh tersangka. Hal tersebut telah sesuai dengan Pasal 109 ayat (1) KUHAP yang menyatakan bahwa "Dalam hal penyidik telah mulai melakukan penyidikan suatu peristiwa yang merupakan tindak pidana, penyidik memberitahukan hal itu kepada penuntut umum". Surat tersebut memuat informasi mengenai nama dan jabatan penyidik yang diperintahkan untuk menangani kasus tersebut serta wewenang yang dimiliki oleh tiap penyidik yakni melakukan tindakan penyidikan terkait dugaan adanya TPPO, membuat rencana penyidikan serta melaporkan setiap perkembangan pelaksanaan penyidikan tindak pidana pada kesempatan pertama kepada pimpinan.

Keluarnya Surat Penyidikan mengharuskan Direktur Reserse Kriminal Umum Polda Jatim menerbitkan Surat Perintah Dimulainya Penyidikan Nomor: B/434/IX/2017/Ditreskrimum, tanggal 4 September 2017. Surat ini merupakan pemberitahuan kepada Kepala Kejaksaan tentang dimulainya penyidikan yang dilakukan oleh penyidik Polri.

Dikeluarkannya Surat Perintah Penyidikan dan SPDP mengharuskan setiap penyidik yang namanya telah tercantum mengadakan pertemuan untuk membahas manajemen serta rencana penyidikan dalam kasus tersebut yang mencakup jadwal dan kegiatan penyidikan. Hal tersebut sesuai dengan Pasal 1 angka (3) dan Pasal 17 Perkap Nomor 14 Tahun 2012 Tentang Manajemen Penyidikan Tindak Pidana yang menyatakan bahwa "Manajemen Penyidikan adalah serangkaian kegiatan penyidikan yang meliputi perencanaan, pengorganisasian, pelaksanaan, pengawasan dan pengendalian" dan "Sebelum melakukan penyidikan, penyidik wajib membuat rencana penyidikan".

Setelah proses penyidikan dimulai, Penyidik menetapkan PFA (21 Tahun) dan KSN (47 Tahun) sebagai tersangka dalam kasus tindak pidana perdagangan orang. Terhadap tersangka PFA dilakukan penahanan berdasarkan Surat Perintah Penahanan Nomor: SPP/104/IX/2017/Ditreskrimum, tanggal 5 September 2017 sejak tanggal 5 September 2017 sampai dengan 24 September 2017 dan telah dibuatkan Berita Acara Penahanan tanggal 5 September 2017.

Untuk penanganan bagi korban Subdit IV Renakta Ditreskrimum Polda Jatim akan melayani korban di unit PPA/ RPK. Mengenai BAP terhadap korban, penyidik memprioritaskan menggunakan BAP Sumpah dan di rekam video, hal ini mengingat adanya traumatik yang mungkin masih dirasakan korban. Penyidik wajib merahasiakan identitas korban.

Penyidik dalam hal ini wajib memberikan informasi mengenai hak restitusi yang merupakan hak pembayaran ganti kerugian yang dibebankan kepada pelaku berdasarkan putusan pengadilan yang berkekuatan hukum tetap. Bila korban menuntut hak restitusi maka penyidik membantu mengajukan tuntutan restitusi dalam BAP. Jika korban sakit/trauma maka penyidik harus merekomendasikan pada Pusat Pelayanan Terpadu (PPT). Bila korban butuh perlindungan maka harus direkomendasikan ke Lembaga Perlindungan Saksi dan Korban (LPSK).

\section{Kendala-kendala penyidikan tindak pidana perdagangan manusia melalui sosial media}

Faktor-Faktor yang mempengaruhi penegakan jukum, disebutkan oleh soerjono soekanto (2004:8) adalah :

Faktor hukumnya sendiri: (1) Tidak adanya aturan yang secara khusus mengatur mengenai perdagangan orang dengan media sosial sebagai sarananya. Ketiadaan aturan khusus yang mengatur penggunaan media sosial sebagai sarana kejahatan perdagangan orang, membuat penyidik terkadang mengalami kesulitan untuk menentukan ancaman pasal yang digunakan, yakni antara penggunaan UU PTPPO dan UU ITE, (2) Ambiguitas Istilah Korban Dalam UU PTPPO Korban juga didefinisikan oleh van Boven dalam Rena Yulia (2010:51), yang merujuk kepada Deklarasi Prinsip-prinsip Dasar Keadilan bagi Korban Kejahatan dan Penyalahgunaan Kekuasaan sebagai berikut : Orang yang secara individual maupun kelompok telah menderita kerugian, termasuk cedera fisik maupun mental, 
penderitaan emosional, kerugian ekonomi atau perampasan yang nyata terhadap hak-hak dasarnya, baik karena tindakannya (by act) maupun karena kelalaian (by omission). Menurut J.E. Sahetapy dalam Muhadar (2006.) Seseorang yang tidak mengalami viktimisasi, maka ia tidak bisa dikategorikan sebagai korban. Artinya ada permasalahan dalam penerapan UU PTPPO dalam penanganan kasus TPPO yang mana beberapa korban ternyata tidak dalam kondisi sebagaimana disebutkan dalam Pasal 1 ayat 3 UU PTPPO yakni kondisi dimana seorang korban adalah seseorang yang mengalami penderitaan psikis, mental, fisik, seksual, ekonomi, dan/atau sosial, yang diakibatkan tindak pidana perdagangan orang. Hal ini tentunya menjadikan berbagai opini negatif terhadap institusi Polri yang akan dianggap berat sebelah dalam penanganan kasus TPPO dengan kondisi semacam itu. Padahal hal ini dikarenakan penjeratan menggunakan UU PTPPO harus ada unsur pelaku dan korban, yang mana untuk memenuhi syarat adanya korban tersebut satu satu jalan adalah dengan menjadikan seseorang sebagai korban walaupun ia pada dasarnya tidak merasa mengalami penderitaan psikis, mental, fisik, seksual, ekonomi, dan/atau sosial.

Faktor penegak hukum, dalam kajian penelitian ini penulis memaparkan kendala dari Tim Cyber Troops dan anggota Subdit IV Renakta Polda Jatim yaitu: (1) Pengetahuan (Knowledge), masih adanya sebagian anggota tim cyber troops kurang memiliki pengetahuan detil mengenai search engine optimization (SEO) untuk memonitoring big data di medsos dan media online dalam rangka meminimalisir akun fiktif, berita hoax, ujaran kebencian, dan terutama terhadap berbagai hal terkait indikasi pidana misalnya perdagangan orang yang terselubung dengan bebagai iklan pekerjaan ataupun modus lain. (2) Keterampilan (Skill), kurang terampil melakukan penetrasi dalam grup grup media sosial yang terindikasi digunakan untuk melakukan transaksi perdagangan orang secara terselubung. (3) Sikap/perilaku (Attitude), adanya sebagian personel yang bersikap jenuh dalam mencari postingan, sehingga kurang jeli dan termotivasi membuat maupun mengintegrasikan akun medsos yang dimiliki dengan saling berteman, ataupun follow antar medsos yang dimiliki. Kemudian, Kendala Personil Sudit IV Renakta: Kendala utama pada indikator penegak hukum ini adalah karena kurang maksimalnya pelayanan konseling untuk korban TPPO. Penyebab utamanya adalah personil Subdit IV tidak ada yang mempunyai background pendidikan psikologi.

Faktor sarana atau fasilitas yang mendukung penegakan hukum, berdasarkan observasi penulis, sarana dan prasarana yang ada saat ini tidak memadai sehingga menyulitkan dalam proses penyidikan. Terbatasnya fasilitas RPK di Unit PPA Subdit IV Renakta Polda Jatim yang hanya memiliki 2 (dua) ruangan yang digunakan dalam penanganan perkara, dari 5 (lima) ruangan yang seharusnya dimiliki Unit PPA.

Faktor kendala pada faktor masyarakat adalah pada tingkat literasi media masyarakat saat ini khususnya remaja. Dengan minimnya tingkat literasi media khsuusnya di kalangan remaja hal tersebut tentunya memicu kekhawatiran tersendiri akan maraknya kejahatan TPPO melalui media sosial. Sebagaimana telah dijelaskan pula diatas bahwa saat ini perekrutan korban TPPO atau human trafficking sudah tidak lagi terfokus di jalanan atau tempat-tempat umum. Sasaran mereka sekarang adalah dunia online yang banyak diakses oleh calon korban potensial yang mana kebanyakan dari calon korban potensial itu adalah anak-anak dan remaja pemilik akun media sosial yang mereka operasikan sendiri dengan berbagai keterbatasan literasi media yang mereka dapatkan.

Faktor budaya, kenyataan kini masalah trafficking bukan hanya disebabkan oleh kemiskinan, utang piutang, riwayat dalam keluarga dan rendahnya kontrol sosial. Akan tetapi dengan perkembangan dan kemajuan jaman, masalah trafficking dipengaruhi dengan munculnya gaya hidup hedonisme seseorang untuk mendapatkan persepsi status sosialnya di masyarakat (Subarisman, 188). Jika budaya hedonisme tetap mengakar kuat di jiwa masyarakat atau lebih khusus bagi remaja saat ini maka akan tetap tumbuh subur pulalah kasus-kasus TPPO karena sebagaimana dalam penelitian diatas disebutkan bahwa akibat budaya hedonisme adalah adanya pergaulan bebas serta sikap yang ingin mendapat banyak uang dengan cara cepat dan mudah.

Berkaitan dengan pemecahan masalah dalam kendala penegakan hukum, pemecahan masalah faktor hukum, hukum pidana harus lebih responsif terhadap berbagai modus kejahatan prostitusi yang 
berkembang di masyarakat. Hukum responsif harus dilakukan dengan cara mendorong instrumeninstrumen hukum yang lebih dinamis bagi penataan sosial dan perubahan sosial. Hukum harus menjawab keresahan masyarakat atas berbagai fenomena yang melanggar tatanan sosial. Untuk itu, masyarakat membutuhkan perubahan UU terkait karena prostitusi online adalah perbuatan yang tidak sesuai dengan norma agama, kesusilaan, dan kesopanan dalam masyarakat.

Pemecahan Masalah Faktor Penegak Hukum ada du yakni bagi personil tim cyber troops dan bagi personil subdit iv renakta. Solusi bagi personil tim cyber troops, menurut penulis kemampuan Sumber Daya Manusia (SDM) Tim Cyber Troops Di Polda Jatim idealnya adalah sebagai berikut: (1) Kuantitas, dari segi kuantitas diharapkan anggota tim cyber troops tidak dibebani tugas rangkap agar dapat saling memberikan feed back antar tim yang ada pada tingkat Polsek, Polres hingga Polda. (2) Kualitas, pentingnya melakukan pembinaan agar dapat meningkatkan kompetensi. Maka diharapkan pimpinan dapat melakukan pembinaan personel melalui pemberian pendidikan kejuruan maupun peningkatan pelatihan secara kontinyu dengan menyelenggarakan kegiatan tersebut secara terprogram, sistematis dan berlanjut, sehingga diharapkan mampu mengusai teknologi informasi dan komukasi (TIK).

Solusi bagi personil subdit iv renakta, beberapa materi pelatihan konseling yang menurut penulis harus diajarkan agar meningkatkan kompetensi anggota sebagaimana disarikan penulis dari beberapa jurnal, antara lain pelatihan kepribadian, pelatihan menjadi konselor yang efektif, pelatihan pemahaman terhadap korban dalam hal mengungkap masalah dan memahami masalah. Penyidik yang menguasai minimal mengetahui sedikit tentang ilmu psikologi, tidak hanya bisa berguna untuk penangan korban dalam konseling saja, tetapi lebih jauh dapat dengan mudah mengenal watak, pribadi tersangka, sehingga dapat ditentukan teknik-teknik pendekatan yang cocok untuk keberhasilan pemeriksaan yang berlangsung secara manusiawi.

Pemecahan Masalah Sarana, upaya yang dilakukan oleh aparat kepolisian dalam mengatasihambatan di sarana prasarana adalahdengan melengkapi fasilitas di RPK adalah dengan ruangan untuk penanganan perkara seperti, ruang konseling dan pemeriksaan korban, agar korbanmerasa nyaman untuk memberikan keterangan serta terlindungi privasinya. Selain itu agar penanganan korban TPPO di RPK bisa menjadi trauma healing bagi korba, $\mathrm{n}$ maka usulan fasilitas yang harus tersedia dalam ruang tersebut adalah sebagaimana yang diatur dalam Pasal 6 Perkap No. 3 Tahun 2008.

Pemecahan Masalah dari Faktor Masyarakat, humas dan Subdit IV Renakta harus mempunyai capaian konsep keberhasilan masyarakat cerdas media dengan mengarahkan pada kemampuan untuk mem"BUKAMATA". Adagium ini mengartikan bahwa masyarakat harus bisa untuk:

B - Belajar berbagai modus kejahatan di media sosial

U - Unggah hal yang positif, benar dan berguna di Media Sosial

$\mathrm{K}$ - Keamanan akun dan koneksi jaringan tidak disembarang tempat

A - Arahkan member/ follower untuk berhati-hati dengan media sosial

M - Mudahlah untuk selalu curiga

A - Analisa kebenaran info yg diterima dan yg disebarkan

$\mathrm{T}$ - Teman di dunia maya belum pasti teman sejati

A - Awasi anak kita dalam gunakan teknologi

Capaian konsep ini menurut penulis harus di lakukan secara masif dengan mengunggah berbagai konten yang mengajak untuk selalu berhati-hati di dunia maya melalui akun media sosial Resmi Polda Jatim dan seluruh jajarannya. Serta dilakukan pula melalui program Bhabinkamtibmas yang menjadi garda terdepan dalam menghadapi persoalan-persoalan masyarakat dan selain itu harus sering diadakan berbagai workshop dengan konsep untuk mem -"BUKAMATA" masyarakat untuk menjadi masyarakat cerdas media. Sehingga output yang diharapkan adalah kesadaran masyarakat dalam memahami bahaya tindak pidana perdagangan orang yang saat ini menjalankan modusnya melalui media sosial. 
Pemecahan masalah dari faktor budaya, subdit IV Renakta harus bekerja sama dengan Bidhumas Polda Jatim melalui personil Bhabinkamtibmasnya untuk melakukan tindakan-tindakan persuasif melalui berbagai program yang sifatnya edukasi keluarga, sekolah dan masyarakat untuk menangkal budaya hedonisme.

\section{Simpulan}

Pelaku perdagangan orang melalui media sosial dengan modus prostitusi melakukan pendekatan pada korbannya melalui cara pemenuhan kebutuhan emosional calon korbannya sehingga terjalin hubungan yang baik antara pelaku dan calon korbannya. Selanjutnya jika korban sudah terjerat maka pelaku melakukan penawaran-penawaran dilakukan pada Korban untuk bisa mendapatkan penghasilan tambahan. Untuk kemudian jika ada ketetarikan maka pelaku menggunakan Grup Line yang berisi akun-akun pria yang bersedia membooking untuk menawarkan wanita wanita tersebut. Modus TPPO berikutnya adalah melalui tenaga kerja ilegal. Ciri modus ini adalah dengan membuka iklan di media sosial dengan kriteria yang tidak masuk akal, misalnya gaji yang ditawarkan selangit tapi tidak membutuhkan pengalaman kerja, menggunakan alamat email gratisan sebagai informasi pekerjaan misalnya pakai yahoo atau gmail serta kontak info yang dipakai adalah dengan nomer HP. Selanjutnya mengenai modus perdagangan orang dengan modus Adopsi ilegal saat ini banyak menggunakan instagram dengan menyamarkan aksinya misalnya menggunakan akun "Konsultasi Hati" yang mana ternyata modusnya adalah menampung bayi bayi hasil luar nikah untuk kemudian dilakukan penawaran adopsi secara ilegal pada orang lain. Mekanisme penyelidikan berbagai modus TPPO yang dilakukan di media sosial awalnya diketahui dari cyber patrol Tim Cyber Troops yang kemudian meneruskan penyelidikan ke Subdit IV Renakta.

Kendala penanganan tindak pidana perdagangan orang dari faktor hukumnya adalah tidak adanya aturan yang secara khusus mengatur mengenai perdagangan orang dengan media sosial sebagai sarananya serta adanya ambiguitas istilah korban dalam UU PTPPO. seharusnya DPR dan pemerintah melakukan revisi terhadap aturan perundang-undangan terkait, terutama UU ITE dan UU Perdagangan Orang agar kegiatan prostitusi online dapat dipidana tanpa melanggar asas legalitas dan hak asasi manusia. Kendala penegakan hukum dari penegak hukumnya adalah dikarenakan kurang terampilnya anggota Tim Cyber Troops melakukan penetrasi dalam grup grup media sosial, timbulnya kejenuhan, serta kurang terampilnya pengetahuan tentang search engine optimization.

\section{Daftar pustaka}

Anggrahini NK (2016) Human Trafficking dan Kemiskinan. Dalam: allennelbercerita.wordpress.com. Diakses pada 15 Januari 2020.

Ardianto E (2004) Komunikasi Massa: Suatu Pengantar. Bandung: Simbiosa Rekatama Media.

Azad A (2018) Recruitment of migrant workers in Bangladesh: Elements of human trafficking for labor exploitation. Journal Human Trafficking 5 (2):1-21.

Belanger D (2014) Labor migration and trafficking among vietnamese migrants in asia. American Academy of Political and Social Science 653 (1):87-106.

Bungin B (2004) Metode Penelitian Kualitatif. Jakarta: PT Rajagrafindo, Persada.

Carr B (2012) When federal and state systems converge: Foreign national human \& trafficing victim whitin juvenile and family court. Juvenile and Family Court Journal 63 (1):77-90.

Engkus H \& Saminnurahmat K (2017) Perilaku narsis pada media sosial di kalangan remaja dan upaya penanggulangannya. Jurnal Penelitian Komunikasi 20 (2):121-134.

Fraser C (2016) An analysis of the emerging role of social media in human trafficking: Examples from labour and human organ trading. International Journal of Development Issues 15 (2):98-112

Hanifah A (2008) Perdagangan perempuan dan anak: Kajian faktor penyebab dan alternatif pencegahannya. Jurnal Penelitian dan Pengembangan Kesejahteraan Sosial 13 (2):46-60.

Honeyman KL, Stukas AA \& Marques MD (2016) Human trafficking: Factors that influence willingness to combat the issue. Journal of Applied Social Psychology 46 (9):529-43.

Kaplan AM \& Haenlien M (2010) Users of the world, Unite! The challenges and opportunities of social media. Business Horizons 53 (1):59-68. 
Latonero M (2011) Human Trafficking Online: The Role of Social Networking Sites and Online Classifieds. Los Angeles: University of South California.

Makarao MT (2014) Pemberantasan tindak pidana perdagangan orang. Veritas 5 (1):1-27.

McClain NM \& Garrity SE (2011) Sex trafficking and the exploitation of adolescents. Journal of Obstetric, Gynecologic, \& Neonatal Nursing 40 (2):243-252.

Nasrullah R (2017). Media Sosial: Perspektif Komunikasi, Budaya, dan Sosioteknologi. Bandung: Remaja Rosdakarya.

Plantika Y (2019) Faktor penyebab perdagangan orang di wilayah hukum Polres Malang Kota. Jurnal Sosiologi Dialektika 14 (1):9-15.

Prabuningrat RG (2015) Faktor penyebab terjadinya perdagangan anak di Kota Pontianak ditinjau dari sudut kriminologi. Gloria Yuris 3 (2):11-21.

Sanapiah F (1990) Penelitian Kualitatif (Dasar-Dasar dan Aplikasi). Malang: YA3 Malang.

Sanchez R \& Stark SW (2014) The hard truth about human trafficing. Nursing Management 45 (1):1923.

Sarkar S (2015) Uses of technology in human trafficking networks and sexual exploitation: A Cross sectional multi-country study. Transnational Social Review 5 (1):55-68.

Suyanto B (2013) Masalah Sosial Anak. Jakarta: Kencana Prenada Media Grup.

Wheaton EM, Schauer EJ, \& Galli TV (2010) Economics of human trafficking. International Migration 48 (4):114-41.

Whiters M (2019) Social Media Platforms Help Promote Human Trafficking. Dalam: https://www.psychologytoday.com/us/blog/modern-day-slavery/201911/social-mediaplatforms-help-promote-human-trafficking. Diakses 13 Desember 2019.

Whitman A \& Gray DH (2015) Transnational human trafficking. Global Security Study 6 (3):11-18.

Winterdyk J \& Reichel P (2010) Introduction to special issue: Human trafficking issuees and perspectives. European Journal of Criminology 7 (1):5-10.

Wulandari C \& Wicaksono SS (2014) Tindak pidana perdagangan orang (human trafficking) khususnya terhadap perempuan dan anak: Suatu permasalahan dan penanganannya di Kota Semarang. Yustisia 90:15 - 26.

Yin RK (2011) Studi Kasus: Desain dan Metode. Jakarta: PT Raja Grafindo Persada. 